\title{
REPRESENTASI PEREMPUAN DALAM MAJALAH AYAH BUNDA
}

Oleh :

Sri Puji Astuti

Fakultas Ilmu Budaya Universitas Diponegoro

\begin{abstract}
Ayah Bunda Magazine is a magazine aimed at women and men who already have a child and married but have not obtained offspring. Nevertheless, this paper contains more issues related to women. Therefore, in this magazine allegedly many use the term that represents women. How the representation of women in the Ayah Bunda magazine which is discussed in this paper is. Method of collecting data which was used in this study was the scrutinizing method followed by technique noted. Discourse analysis used content analysis. Based on the results of the study was found that women's representation in the Ayah Bunda magazine shown with a term that refers to the female nature wasteful, less logical, anxious. The appearance should be interesting, limited to the motion, like a complicated thing, and prioritize domestic interests.
\end{abstract}

Keywords: representation, woman, Ayah Bunda magazine

\section{PENDAHULUAN}

Bahasa digunakan sebagai sarana untuk menyampaikan pesan. Majalah merupakan salah satu media massa untuk menyampaikan pesan. Majalah Ayah Bunda merupakan salah satu majalah yang ditujukan untuk orang tua. Majalah ini berisi berbagai ilmu dalam menghadapi masalah keluarga mulai persiapan mengandung sampai balita. Majalah ini ditujukan kepada perempuan maupun lakilaki yang sudah mempunyai anak maupun yang telah menikah tetapi belum memperoleh keturunan. Meskipun Majalah ini berjudul Ayah Bunda, masalah yang dibahas banyak yang berhubungan dengan perempuan. Hal ini sesuai dengan pendapat Hidayati (2006) yang menyatakan bahwa tanpa disadari, perempuan cenderung dijadikan objek terbitnya majalah, tabloid, dan berbagai macam produk telah menggiring perempuan menjadi sasaran kaum kapitalis. Hal tersebut mengakibatkan sesuatu yang sebetulnya tidak diperlukan perempuan, dibuat sedemikian rupa sehingga perempuan merasa wajib memiliki/menggunakannya.

\section{PERMASALAHAN}

Berdasarkan latar belakang di atas, dalam makalah ini dibahas bagaimana representasi perempuan dalam majalah Ayah Bunda.

\section{REPRESENTASI}

Menurut Eriyanto (2001:113-114 ) istilah representasi menunjuk pada bagaimana seseorang, suatu kelompok, gagasan, atau pendapat tertentu ditampilkan dalam pemberitaan. Lebih lanjut dikatakan bahwa representasi penting dalam dua hal. Pertama apakah seseorang, kelompok, atau gagasan tersebut ditampilkan sebagaimana mestinya. Kedua, bagaimana representasi tersebut ditampilkan. Representasi tersebut dapat ditampilkan dengan kata, kalimat, atau dengan bantuan foto. Pemakaian katakata, kalimat atau proposisi tertentu membawa makna tertentu ketika diterima oleh khalayak. 
Menurut Jun Kuncoro $\mathrm{H}$ (1998:217) bahasa yang digunakan seharihari bukan saja sebagai alat untuk berkomunikasi. Bahasa juga dapat digunakan sebagai sarana sosialisasi dan pelestarian terhadap suatu sikap atau nilai. Bahasa berpengaruh terhadap gerak fisikal manusia yang menggunakannya melalui kata-kata tertentu. Bahasa dengan kekuatan tersembunyi dapat melestarikan nilai dalam masyarakat dan memdorong masyarakat untuk melakukan aksi-aksi sosial berdasarkan keyakinan yang dikristalkan dengan bahasa.

Bahasa yang digunakan dalam media massa dapat menciptakan realitas tertentu kepada khalayak. Burke (dalam Eriyanto, 2001:119) menyatakan bahwa kata-kata yang digunakan dalam media massa dapat membatasi seseorang melihat perspektif lain, menyediakan aspek tertentu dari suatu peristiwa dan mengarahkan bagaimana khalayak harus memahami suatu peristiwa.

\section{METODE PENELITAN}

Data penelitian ini berupa penggalan wacana yang merepresentasikan perempuan . Data yang digunakan dalam penelitian ini bersumber dari Majalah Ayah Bunda. Di dalam kegiatan pengumpulan data digunakan metode simak. Data dipilih sesuai dengan kebutuhan penelitian. Teknik yang digunakan adalah teknik catat. Teknik ini digunakan untuk mencatat data yang telah diamati. Dalam analisis data digunakan metode analisis isi yaitu metode yang digunakan untuk menarik simpulan melalui usaha menemukan karakteristik pesan.

\section{PEMBAHASAN}

Berdasarkan hasil penelitian representasi perempuan dalam majalah Ayah bunda dapat dilihat dalam data berikut ini.

Mirza Chaidir (27) PNS Kemenkeu

(1) Ibu yang merokok selama hamil akan "memprogram " anak yang dikandungnya untuk menjadi perokok pula. Anak yang lahir dari ibu perokok berpeluang 3 kali lipat mulai merokok sebelum usia 14 tahun (AB, 26 Sep 2011 hal 36)

Dalam wacana ini perilaku ibu yang merokok dianggap tidak baik karena akan melahirkan anak yang perokok pula. Bahkan anak yang dilahirkannya akan merokok di usia sebelum 14 tahun. Wacana ini tentunya menakut-nakuti ibu hamil yang merokok karena akan melahirkan anak yang perokok pula. Wacana ini sebenarnya melarang ibu yang sedang mengandung merokok. Hal itu juga sesuai dengan informasi yang tertera dalam setiap bungkus rokok.

Dalam majalah Ayah Bunda perempuan digambarkan orang yang boros hal tersebut dapat dilihat dalam wacana berikut ini.

(2) Ibu Tidak tahan Belanja

Mobil-mobilan untuk Daniel dan Allexander yang kini sedang gemar dengan film the Cars, Saya tidak bisa berhenti membelikannya

Ribka Rasmina Marisi (PNS Bogor)

(AB, 26 Sep 2011 hal 114)

Wacana (2) menunjukkan bahwa perempuan identik dengan suka berbelanja. Judul wacana (2) menggambarkan bahwa perempuan mempunyai sifat yang boros. Hal tersebut ditunjukkan dalam kalimat ibu tidak tahan berbelanja. Bahkan perempuan dalam wacana ini juga digambarkan kurang dapat memperthitungkan kebutuhan. Hal tersebut dapat dilihat dalam kalimat saya tidak bisa berhenti membelikannya.

Perempuan dalam majalah Ayah Bunda digambarkan sebagai orang yang kurang rasional. Hal tersebut dapat dilihat dalam wacana berikut ini.

(3) Menjadi ibu dapat membuat seorang wanita melakukan hal-hal yang tidak wajar, Saya rela berjam-jam mengelilngi toko perlengkapan bayi, 
hanya untuk mendapatkan sebuah stoller yang sempurna untuk Kase (Penyanyi) (AB, 2 Januari 2011 hal 20)

(4) Hari Pertama Kerja

Saya lupa membawa pakaian anak, alhasil rindu luar biasa menyelimuti hari pertama saya. Untungnya jarak kantor dan rumah bisa ditempuh dalam 10 menit. Jam istirahat tiba, saya menjenguk rumah. Lumayan untuk menghilangjan kerinduan (Ita Ratnawati)

(AB,11 April 2011 halaman 106)

Dalam wacana (3) perempuan digambarkan tidak rasional karena perempuan digambarkan rela menghabiskan waktu berjam-jam hanya untuk membeli sebuah stoller. Hal ini menunjukkan bahwa perempuan suka menghabiskan waktu untuk hal-hal yang tidak perlu. Dalam wacana (4) perempuan digambarkan orang yang tidak rasional karena saat seorang ibu yang meninggalkan anaknya untuk bekerja di hari pertama lupa membawa pakaian anaknya. Hal tersebut membuat ibu kangen pada buah hatinya.

Perempuan dalam majalah Ayah Bunda digambarkan harus tampil cantik dan menarik baik saat hamil maupun setelah melahirkan.

\section{(5) ...}

\section{SETELAH 3 BULAN}

Pada masa ini adalah penting untuk Anda punya percaya diri dan tampil menarik dan merasa diri masih menarik. Curi waktu untuk kembali merawat kulit yang kering atau rambut yang sebelumnya menjadi lepek berminyak atau justru kering dengan mendatangi pusat perawatan kulit dan rambut. Sediakan waktu untuk penampilan diri yang lebih bersinar dan kesehatan jiwa yang seimbang itu nyalon, pijat atau sekadar berjalan-jalan dan shopping sendirian. Menjadi ibu bukan berarti Anda mengorbankan diri sendiri menjadi lusuh dan tak cantik. (AB, 2 Januari 2011 halaman 44)

Dalam wacana (5) digambarkan bahwa perempuan yang sedang mengandung setelah tiga bulan dianggap percaya dirinya kurang dan penampilan menjadi kurang menarik. Perempuan yang sedang mengandung juga digambarkan berkulit kering, berambut lepek berminyak atau bahkan kering. Dalam wacana ini juga dipertegas dengan kalimat menjadi ibu bukan berarti Anda mengorbankan diri sendiri menjadi lusuh dan tak cantik. Jadi, wacana (5) mengharapkan perempuan yang sedang mengandung harus tetap berpenampilan menarik dengan menyarankan pergi ke salon untuk merawat tubuhnya. Hal yang sama juga dapat dilihat dalam wacana (6).

(6) Walau sedang hamil, penampilan saat ke kantor harus tetap gaya dan profesional (AB, 26 September 2011 halaman 51)

Dalam wacana (6) perempuan yang sedang mengandung dan bekerja di kantor diharapkan tetap tampil gaya dan profesional. Hal ini dikarenakan kadangkadang perempuan yang sedang menggandung sering menggunakan baju yang sangat longgar sehingga kurang modis.

Wacana (7) berikut ini menggambarkan seorang perempuan setelah melahirkan berjerawat dan kulitnya menjadi belang.

(7) Kembalikan Indahku

Yang belang, yang berjerawat...

Diperbaiki setelah melahirkan agar indah kembali (AB, 4 Juli 2011 halaman 43)

Judul dalam wacana (7) kembalikan indahku menggambarkan perempuan tidak ikhlas atau tidak bisa menerima kondisi kulitnya setelah melahirkan. Kulit yang belang di bagian perut perempuan setelah melahirkan memang banyak terjadi. 
Hal tersebut mengakibatkan tampilan wanita dianggap kurang menarik. Dalam wacana ini perempuan diharapkan merawat kulitnya setelah melahirkan.

(8) PINTAR BELANJA BAJU HAMIL TIDAK PERLU BURU-BURU BELI Tunggu sampai trisemester pertama lewat untuk berbelanja baju hamil, setelah perut makin membuncit dan baju biasa sudah makin sesak.

Lakukan belanja dengan tenang, tak perlu kalap berbelanja setiap bulan. Beli sesuai kebutuhan.

Wacana di atas merepresentasikan bahwa perempuan yang hamil biasanya segera membeli baju hamil meskipun perutnya belum kelihatan besar. Begitu juga dalam judul wacana ini menggambarkan bahwa perempuan dianggap pintar berbelanja baju hamil jika kehamilannya telah berusia tiga bulan. Jadi, wacana ini mengharapkan perempuan yang usia kehamilannya di bawah tiga bulan belum perlu membeli baju hamil karena biasanya usia kandungan tersebut masih bisa mengenakan baju yang biasa dipakai sebelum mengandung. Apabila baju yang tersedia sudah tidak cukup lagi, ibu hamil disarankan membelinya. Sesuai kebutuhan. Jadi, tidak perlu membeli baju hamil terlalu banyak. Hal tersebut dapat dilihat dalam kalimat lakukan belanja dengan tenang, tak perlu kalap berbelanja setiap bulan.

Perempuan yang hamil tanpa direncanakan dalam majalah Ayah Bunda digambarkan cemas. Bahkan kehamilan yang pertama pun kalau tidak direncanakan juga membuat perempuan cemas. Hal tersebut dapat dilihat dalam wacana berikut ini.

(9) Hamil Terlalu cepat

Berita kehamilan membuat perasaan saya tidak karuan!

Buyar semua rencana. Terbayang bagainama beratnya hamil sambil kuliah. Belum lagi rasa cemas selama tiga bulan itu saya pernah minum pil KB. Saya khawatir terjadi apa-apa pada janin yang sedang dikandung. Dan hal lain yang tidak kalah penting adalah secara finansial kami belum siap. Rumah pun masih dipinjami keluarga. Namun, suami menguatkan bahwa semuanya akan baik-baik saja (AB, 2 Januari 2011 Hal 34)

Kecemasan perempuan yang mengandung tanpa direncanakan digambarkan dengan jelas. Dalam wacana tersebut kecemasan perempuan disebabkan kurangnya persiapan mengandung seperti perempuan masih kuliah dan belum siap secara finansial. Dalam wacana ini meskipun perempuan digambarkan orang yang sangat cemas karena perempuan mengandung tanpa direncanakan namun laki-laki digambarkan orang yang santai dalam menghadapi masalah. Hal tersebut dapat dilihat dalam kalimat namun suami menguatkan bahwa semuanya akan baikbaik saja.

Perempuan yang sedang mengandung digambarkan sebagai orang yang geraknya sangat terbatas. Perhatikan wacana berikut ini.

(10) PINDAH KERJA SAAT HAMIL

Bosan dengan perusahaan sekarang, Anda ingin "terbang" ke perusahaan lain. Masalahnya, saat ini Anda sedang hamil...

Pikirkan dengan matang. Tanyakan kembali pada diri Anda, apa benar harus pindah kerja sekarang juga? Pertimbangkan... $(A B, 2$ Januari 2011 Hal 94)

Perempuan yang sedang hamil digambarkan mempunyai keterbatasan gerak. Wacana di atas menggambarkan seorang wanita yang hamil dan ingin pindah kerja disarankan untuk berpikir atau mempertimbangkan dulu karena perempuan yang hamil dan bekerja di tempat yang baru dikhawatirkan tidak mendapatkan fasilitas seperti yang harus 
didapatkan dari perusahaan semula. Lebih dari itu perempuan yang sedang mengandung harus menyesuaikan lagi dengan tempat kerja yang baru. Hal ini merupakan proses yang agak sulit.

Perempuan dalam wacana berikut ini digambarkan sebagai orang yang mandiri.

(11) Dapat menyelesaikan masalah keluarga dan pekerjaan dengan baik

Begini rahasia mereka mnjadi Bunda Super

Kuncinya Kerjasama

Sebagai orang Bali, saya punya seabrek kesibukan dengan upacara adat, di samping praktik sebagai dokter umum, urusan rumah tangga dan anak. Saya memutuskan untuk tidak menggunakan jasa pengasuh mesti saya tahu risikonya repot. Syukur, suami, ibu dan mertua selalu membantu. Kami bisa bekerja sama dengan baik. Kalau saya sedang mempersiapkan segala sesuatu untuk upacara adat bersaama ibu dan mertua, suami menjaga anak. Saya masih bisa memberi ASI di sela-sela praktik dokter. Ketika harus jaga saya menyetok ASI di rumah. Nanti ibu saya yang akan memmberikan ASI perah kepada Abi. Selain itu, setiap pagi sebelum bertugas, saya mnyempatkan diri membuat pureee untuk Abi. (AB, 2 Januari $2011 \mathrm{Hal}$ 99)

Perempuan dalam wacana di atas berprofesi sebagai dokter. Sebagai seorang dokter tentu perempuan sibuk. Namun, perempuan dalam wacana ini digambarkan sebagai orang yang suka bekerja karena dia tidak mempunyai pengasuh. Setiap pagi ia mempersiapkan makanan untuk anaknya. Bahkan suaminya pun mau membantu istri menjaga anak mereka. Dalam wacana ini diguakan istilah bunda super. Sebuatan bunda super dalam wacana ini diperuntukkan kepada perempuan yang dapat membagi watunya dengan baik. Perempuan masih bisa menyempatkan diri untuk mengurus keluarga dengan baik meskipun ia juga bekerja.

Dalam majalah Ayah Bunda juga ditemukan istilah ibu jempolan. Perhatikan wacana berikut ini.

(12) Giat berkampanye ASI dan RUM (Rational Uses of Mediciine) sebagai duta ibu hamil tahun 2010 sekaligus menyusui tandem, menjadikan Widi Mulia (32) layak disebut ibu jempolan. (AB,7 April 2011)

Dalam wacana (11) perempuan disebut ibu jempolan karena giat berkampanye ASI dan RUM sekaligus menjadi duta ibu hamil dan menyusui. Hal perlu dipertimbangkan banyak ibu yang ingin memberikan asi pada bayinya tetapi ibu tersebut bermasalah dengan asinya.

(13) ... pernahah terlintas di benak Bunda, si kecil bahkan sudah harus berjuang sejak masih berada dalam kandungan? Hasil penelitian yang dilakukan sejak dua dekade lalu membuktikan bahwa ancaman terhadap keberlangsungan hidup janin menghadang dari berbagai arah tetapi tidak perlu merasa cemas! Pertarungan ini pasti akan dimenangkan si kecil dengan bantuan Bunda. (AB 17 januari 2011 hal 27)

Wacana di atas mempresentasikan perempuan yang sedang menganadung adalah pahlawan bagi janin yang dikandungnya. Hal tersebut disebabkan banyaknya ancaman terhadap janin selama dalam kandungan. Naamun, dalam wacana tersebut dijelaskan bahwa pertarungan ini pasti akan dimenangkan si kecil dengan bantuan bunda. Wacana ini mempersuasi perempuan agar hati-hati pada waktu mengandung.

Peran perempuan (ibu) sangat penting bagi anaknya terutama ketika 
masih bayi. Hal tersebut dapat dilihat dalam wacana berikut ini.

(14) Setiap kali seorang ibu menyentuh bayinya, dia membuat bayinya lebih sehat. Bonding yang kuat antara ibu dan bayi akan memperkuat sistem kekebalan tubuh bayi sehingga dia terlindung dari berbagai serangan penyakit. Kekuatan ikatan dan kedekatan ibu dan bayinya akan mengurangi jumlah kunjungan ke dokter anak. Bonding juga membantu memicu perkembangan IQ bayi. Dr Deepak Chopra, pakar endokrinologi. (AB, 31 Januari 2011 hal 36)

Seorang pakar endokrinologi mengatakan bahwa setiap kali ibu menyentuh bayinya, bayi itu akan menjadi lebih sehat. Ikatan ibu dan bayinya akan meningkatkan sistem kekebalan tubuh pada bayi sehingga bayi akan terlindung dari berbagai macam penyakit. Bahkan ikatan ibu dan anak akan memicu perkmbangan IQ. Wacana ini tentunya menjelaskan bahwa kedekatan ibu dan anak sangat penting bagi kesehatan dan perkembangan anak.Hal yang kadang-kadang terjadi adalah ada perempuan (ibu) yang habis melahirkan tidak mau menyusui anaknya karena takut kalau tubuhnya tidak menarik lagi.

(15) Bukan Hanya Suami

Kini sudah tak bisa lagi hanya suami yang menangani dan membereskan keuangan keluarga. Sudah saatnya para istri terlibat dalam masalah pembayaran tagihan, tabungan dan investasi. Setidaknya, cobalah untuk duduk bersama suami Anda sekali dalam sebulan untuk mengetahui dan mempelajari keadaan keuangan keluarga Anda. Bila Anda tak tahu menahu mengenai situasi keuangan keluarga. Anda berada di posisi cukup rentan jika sesuatu terjadi pada pasangan. Misalkan terjadi perceraian, atau pasangan meninggal mendadak. Anda harus mengetahui segala informasi untuk melakukan keputusan bijaksana mengenai masa depan anak.(AB, 28 Februari 2011 halaman 94)

Wacana di atas mempresentasikan bahwa perempuan pada umumnya dianggap orang yang tidak tahu menahu tentang keuangan keluarga. Perepuan dianggap sekadar menerima pemberian uang laki-laki. Bahkan dalam wacana tersebut dijelaskan bahwa apabila perempuan dianggap tidak tahu masalah keuangan keluarga dianggap berada dalam posisi berbahaya. Hal tersebut disebabkan dalam keluarga bisa terjadi perceraian, atau pasangan meninggal mendadak. Oleh karena itu, dalam wacana tersebut disarankan perempuan harus mengetahui segala macam keperluan keluarga termasuk merencanakan masa depan anak.

Perempuan dalam majalah Ayah Bunda direpresentasikan orang yang suka hal yang rumit.

(16) ... Rinta termasuk ibu yang sangat ketat dalam pengasuhan putrinya. Akemi Marishi Suhertian yang kini berusia 9,5 bulan. Waktu makan, makanan atau minuman yang boleh dikonsumsi dan aktivitas rutin yang harus dilakukan Akemi sudah terjadwal.

Dalam wacana di atas perempuan direpresentasikan orang yang menyukai hal yang rumit. Hal tersebut ditunjukkan pada cara pengasuhan anak yang sangat ketat. Semua aktivitas yang dilakukan anaknya (Akemi 9,5 bulan) terjadwal. Bahkan makanan dan minuman yang harus dikonsumsi pun diatur. Dalam kenyataannya anak usia 9,5 bulan terkadang sulit untuk memenuhi jadwal yang ditentukan orang tuanya. 


\section{Perempuan dalam majalah Ayah Bunda dirrepresentasikan mempunyai tugas yang berat terutama menyuapi anak. \\ (17) Senang makan \\ Cara jitu membuat balita suka makan sehingga meringankan tugas ibu.}

(AB,28 Februari 2011 halaman84)

Wacana ini merepresentasikan tugas ibu sangat berat jika anaknya susah makan. Apabila anak suka makan tugas ibu menjadi lebih ringan. Perempuan yang mempunyai anak yang susah makan memang merupakan masalah tersendiri. Hal tersebut disebabkan perempuan harus lebih kreatif membuat makanan agar anaknya tertarik untuk makan.

Perempuan direpresentasikan sebagai guru bagi bagi anaknya. Hal tersebut dapat dilihat dalam wacana berikut ini.

(18) Ajari Aku. Bu...

Stimulasi seawal mungkin dan berulang-ulang, menjadi pembuka yang baik bagi kehidupan bayi.

Sejak awal kehidupannya -dengan kemampuan yang masih sangat terbatas- bayi dapat menyerap bermacam hal yang dilihat dan didalaminya. Orang tua dapat mengajarkan bayinya sejak dini tentang berbagai hal dan bagaimana sebaiknya ia merespon sekelilinlg yang dipandu PASTE- yang merupakan singkatan dari Playing (bermain, Awareness (mengenal diri, orang lain, dan lingkungaan), Singing (bernyanyi) talking (berbicara) danEncourge the challenge (memberi motivasi, semangat)- Anda semakin mantap menstimulasi si buah hati. Dengan begitu, Anda memberikan awal yang baik bagi kehidupan anak. (AB, 28 Februari 2011 halaman 40)

Ibu bagi anaknya merupakan pendidik pertama. Sebagai pendidik pertama ibu harus mengajarkan berbagai hal kepada banyinya. Untuk mengajarkan berbagai hal ada panduanya yaitu PASTE yang merupakan singkatan dari Playing (bermain, Awareness (mengenal diri, orang lain, dan lingkungaan), Singing (bernyanyi) talking (berbicara) danEncourge the challenge (memberi motivasi, semangat).

Apabila orang tua (perempuan) tidak dapat merawat anaknya karena suatu hal, perempuan harus menitipkan anaknya di tempat penitipan anak. Untuk menitipkan anak harus memilih penitipan yang terbaik. Hal tersebut dapat dilihat dalam wacana berikut ini.

(19) Day care teman baru anak

Saking menjamurnya, orang tua mesti selektif memilih day care.

Repot tidak apa-apa, yang penting aman (AB, 28 Februari 2011 halaman 46)

Dalam wacana ini perempuan disarankan untuk memilih day care yang baik meskipun tempatnya agak jauh. Hal tersebut karena day care dibuka di manamanayang mungkin kualitas pelayanannya masih meragukan.

Dalam wacana berikut ini perempan direpresentasikan rela menghabiskan waktunya di rumah bersama dengan buah hatinya.

(20) Nirina Zubir (31) kini tak tertarik mengejar popularitas. Menghabiskan waktu bersama Zivara Ruciagati Syarief (2) tampak lebih menarik baginya. Bahkan sang suami, Ernest Syarief (32) pun berkali-kali menanyakan apakah ia tidak bosan terus-menerus berada di rumah. "Sekarang saya lebih selektif memilih pekejaan. Kalau hasilnya besar, baru saya ambil. Lumayan kan untuk tabungan masa depan Zee. Percuma dong kalau sudah meninggalkan anak di rumah kalau hasil yang didapat sedikit!" kata $\mathrm{Na}$, sapaan akrab Nirinna, jujur. Presenter yang tengah mengandung 
anak kedua ini tidak pernah bosan di rumah karena ia mengisi harinya dengan belajar memasak, menjahit dan berkebun. (AB, 2 Januari 2011 halaman 17)

Kalimat dalam wacana di atas kini tak tertarik mengejar popularitas ini menunjukkan bahwa perempuan setelah berkeluarga terutama yang mempunyai anak biasanya tidak mengutamakan karirnya. Bahkan dalam wacana ini perempuan direpresentasinkan rela di rumah bersama buah hatinya. Dia akan menerima tawaran bekerja apabila hasilnya besar. Sementara kalau hasilnya kecil tidak diambil. Dia memilih di rumah karena dia belajar memasak, menjahit, dan berkebun. Dalam wacana ini perempuan direpresentasikan tidak harus bekerja untuk mencukupi kebutuhan keluarga karena suamilah yang harus bekerja. Dalam wacana ini suami sudah mengizinkan istrinya bekerja, namun istri tetap memilih mengasuh anaknya di rumah kecuali jika tawaran yang diberikan memberi hasil yang besar. Hasil bekerjanya itu pun hanya untuk masa depan anaknya bukan untuk kebutuhan sehari-hari.

\section{SIMPULAN}

Berdasarkan hasil penelitian representasi perempuan dalam majalah Ayah Bunda masih ditunjukkan dengan sifat boros, kurang logis, berpenampilan menarik, mudah cemas, terbatas ruang geraknya, suka yang rumit-rumit, dan mengutamakan kepentingan domestik.

\section{DAFTAR PUSTAKA}

Eriyanto, 2001. Analisis Wacana Pengantar Analisis Teks Media. Yogyakarta: LkiS

Hidayati, Ratna. 2006. "Repreasentasi Perempuan di Media". Makalah ini disampaikan dalam Short Course "Jurnalisme Berperspektif Gender"Denpasar, 22 April http://erhanana.wordpress.com/ (Unduh 13 Mei 2014)
Jun Kuncoro H. 1998. "Bahasa Media Massa Masih Mendeskripsikan Wanita" Wanita dan Media: Konstruksi Ideologi Gender dalam Ruang Publik Orde Baru. ed. Idi Isbandy Ibrahim dan Hanif Suranto. Bandung: PT Remaja Rosdakarya. 